\title{
Models of Charge Distribution in and under Clouds during Snowfall
}

\author{
By Choji Magono \\ Department of Geophysics, Hokkaido University, Sapporo \\ and Keitaro Orikasa \\ Department of Mechanical Engineering for Production, \\ Muroran Technical College, Muroran
}

(Manuscript received 4 August 1966)

\section{Introduction}

In the previous article, the result of observation of the disturbance in the surface electric field caused by snowfall was described by the authors (1966).

From the observational results and the considerations, the authors have obtained the following image for the charge generation of falling snow particles.

1) In calm snowfalls from higher clouds of layer type, snow particles (usually nonrimed snow crystals) were charged negatively by the induction theory.

2) In showery snowfall from a nimbus cloud, graupel or rimed snow crystals were charged positively by friction with non-rimed snow crystals, on the other hand the non-rimed snow crystals obtained a negative charge. Moreover, large snowflakes were charged positively by frictional contact with small snowflakes or single snow crystals. Based on this picture, various types of surface electric field patterns were derived from the distribution of space charge in and under clouds, in the following manner.

\section{Surface field pattern due to showery graupel-fall}

The surface electric fields observed are considered to be caused by the superimposed effect of time change and local change. For convenience sake, only time change was considered at first.

Fig. 1 shows a model of charge distribution in and under a cloud and a surface electric field pattern which was presumed from the charge distribution when a short period graupel-fall occurred during a steady snowfall. The explanation for the codes in the figure is given below.

+ Positive charge due to ions produced by induction mechanism

- Negative charge on snow particles produced by induction mechanism

$\bigcirc$ Graupel not yet charged

$\oplus$ Positive charge on graupel produced by friction
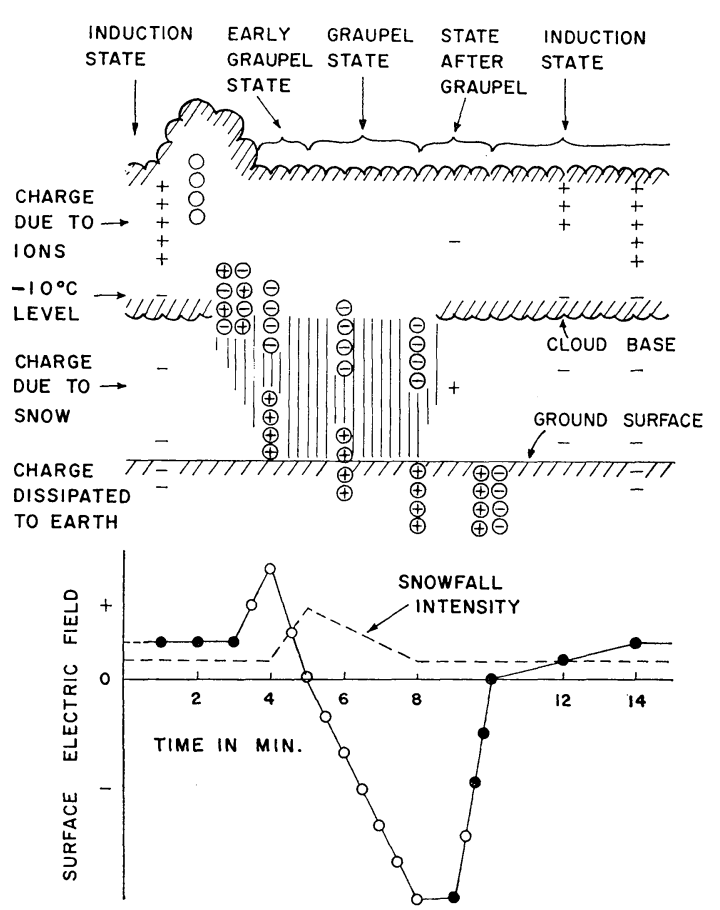

Fig. 1. A proposed model for charge distribution in and under a cloud, and corresponding surface electric field pattern in short period graupel-fall. 
$\ominus$ Negative charge on non-rimed snow crystals produced by friction

The codes written under the ground surface indicate that the charge shown by the codes was already dissipated into the earth. The lower picture shows the assumed time change of surface electric field which is represented in the same manner as in the figures of the previous article (1966). The time scale is common in both pictures.

If a core of graupel is generated in a short period in a stratocumulus cloud, the following four states will be considered for the charge generation of snow particles, namely, "Induction state", "Early graupel state", "Graupel state" and "State after graupel". These states are shown in Fig. 1.

1) Induction state: This is the basic state in which snow crystals are charged negatively by the induction mechanism under a positive field, and positive ions are transported to the upper part of the cloud by a slowly ascending air current. Thus a positive surface electric field is formed as shown at the left end of Fig. 1. Because negative charge on the falling snow crystals will be carried away to ground surface sooner or later, the positive surface electric field increases to a steady value up to the time when the strength of the field becomes balanced with the rate of diffusion of positive ions outward from the cloud. Although the balancing strength is considered to depend on the rate of snowfall, the field usually reaches several hundreds volt $\cdot \mathrm{m}^{-1}$ in the case of Sapporo. The distribution of charge shown at the origin of Fig. 1 indicates this steady state.

2) Early graupel state: If a group of graupel are formed at the upper part of the cloud 2 minutes after the origin and begin to fall, then they will collide with non-rimed snow crystals at the lower part of the cloud or under the cloud base, where charge generation occurs by friction at temperatures warmer than $-10^{\circ} \mathrm{C}$; graupel became positive, non-rimed crystals became negative. Because the graupel fall is more rapid than non-rimed snow crystals, a positive surface electric field is formed as shown at 4 minutes after the origin of Fig. 1. This state is called "Early graupel state" in this paper. In this state with positive graupel fall under positive electric field, an inverse relation does not hold. Because this state is rather transitional and is localized close to ground surface, such patterns of electric field are observed very rarely, as already stated.

3) Graupel state: As the majority of the positive graupel reach the ground surface, the negative space charge due to negative snow crystals above becomes effective on the surface electric field, then the transitional positive field changes to negative. The maximum of snowfall intensity usually coincides with this time as shown at 5 minutes after the origin. If the formation of graupel within the cloud continues, this graupel state will continue as the steady graupel state. It is considered that the negative portion of the waved pattern belongs to this state.

4) State after graupel: After the positive graupel fall to the ground surface is completed, the negative surface field will be maintained further, owing to the negative space charge due to the negative charge on falling non-rimed snow crystals, however the curve of the negative field will ascend gradually. This state is called "State after graupel" which corresponds to the period between 8 and 10 minute in Fig. 1. In this state negative snow crystals fall under a negative field, in other words the phase of change in sign of charge on snow crystals precedes that of surface electric field. Thus the difference in phase between the signs of charge and field was explained. In this state, a possibility is expected that positive snow crystals occur, because falling snow crystals under the negative field in this state will be charged positively by the induction theory as shown at 9 minutes after the origin. After negative snow crystals all reach the ground surface, a positive field will occur again and tendency to a steady value approximately the same as that in the origin may be expected.

If a short period graupel formation occurs in a cloud and the cloud does not move, the 
field pattern as shown at Fig. 1 will be observed, however in an actual case, the cloud moves with respect to the observation point, changing its electrical property. Therefore the four states of cycle described above will not always be observed at a certain point. However when an active cell (single nimbostratus) or successive active cells (successive nimbostratus or stratocumulus) is passing over an observation point, at least one of the states must exist above the point at a time, and other parts of the field pattern as shown in Fig. 1 will be observed around that time. Accordingly it may be possible to estimate the charge distribution in and under a cloud from the pattern of surface electric field. In this case, the rate of snowfall, the type of snow particles also will give useful informa- tion about the charge generation. For such an estimation, several examples of relation between the charge distribution and the surface electric field will be given below.

\section{Presumed charge distribution in and under a single cloud, and corresponding surface electric field}

When a narrow but steady core in the "Graupel state" of a single nimbostratus passes over an observation point as shown in the upper picture of Fig. $2 \mathrm{a}$, a positive field pattern interrupted by a negative sharp peak as seen in the lower picture of the figure will be observed. And the negative peak will timewise coincide with the maximum of snowfall. In this case, negative snow crystals on both sides of the graupel-fall, are consider-

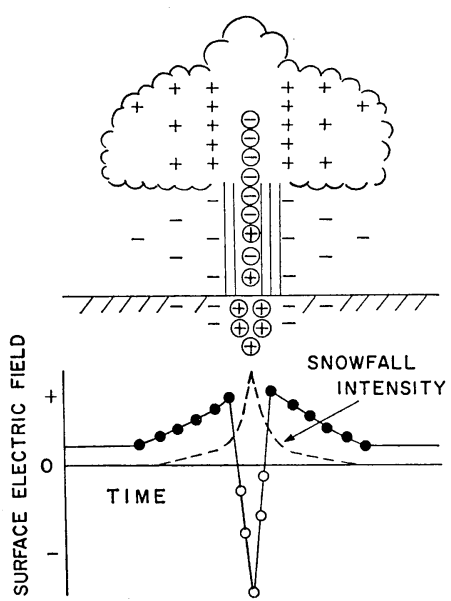

Fig. 2 a. Supposed charge distribution corresponding to a single positive pattern interrupted by two negative peaks.

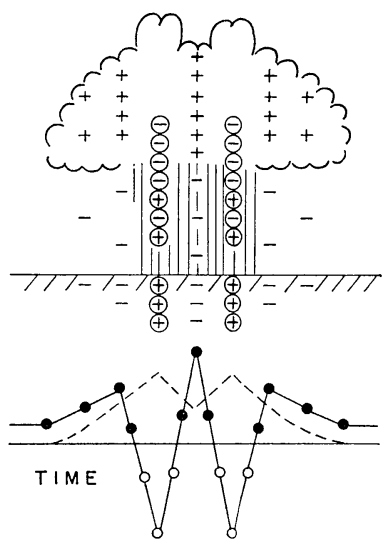

Fig. 2 b. Supposed charge distribution corresponding to a single negative pattern interrupted by a positive peak.

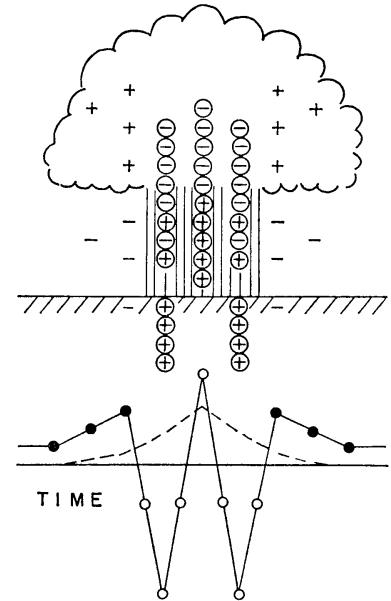

Fig. 2c. Supposed charge distribution corresponding to a single negative pattern interrupted by a positive peak. ed to be electrified by frictional contact with falling graupel or by the induction mechanism. A good actual example of the field pattern of this type was seen at $11^{\mathrm{h}} 13^{\mathrm{m}}$ 10th Feb. 1959 (Fig. 4).

When two cores of graupel state pass, a field pattern as shown in the lower picture of Fig. $2 \mathrm{~b}$ may be presumed. The two maximums of snowfall and the two minimums of electric field are the distinction of this type. The field pattern which was seen at $18^{\mathrm{h}} 30^{\mathrm{m}}$ 6th Dec. 1958 (Fig. 5) is presumed

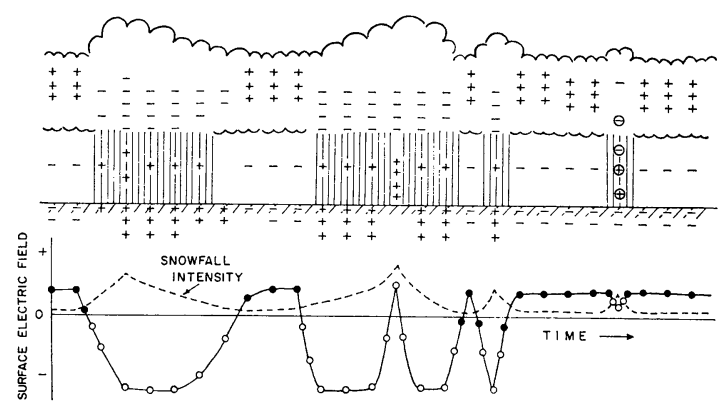

Fig. 3. Supposed charge distribution corresponding to waved pattern with irregular peaks. 


\section{FEB. 1959}

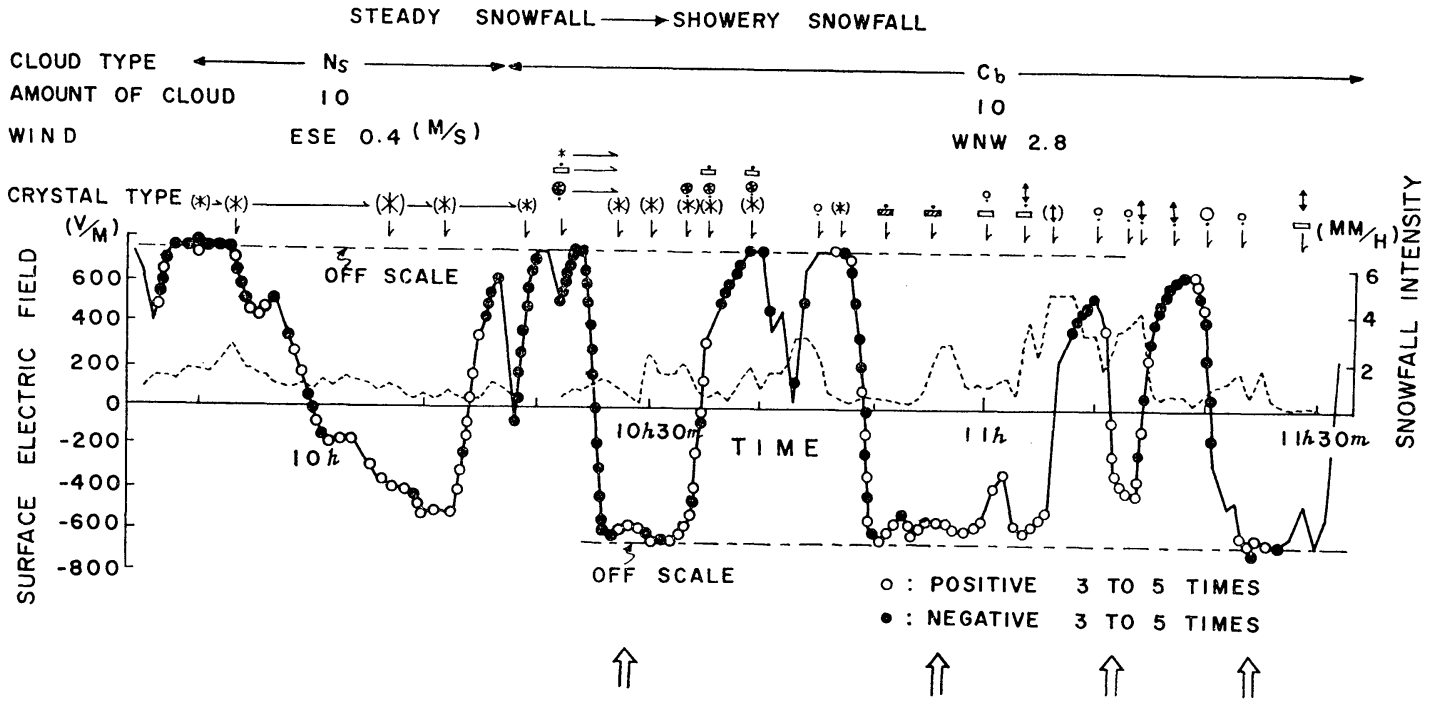

Fig. 4. Charge on snow particles under periodically changing electric field in a continuous snowfall from nimbostratus, 10 Feb. 1959. Size of crystal symbols indicates relative size of snowflakes.

6 DEC. 1958

SNOW SHOWER

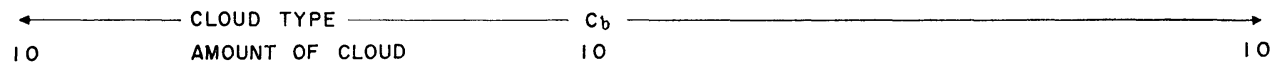

WNW $8.4^{(\mathrm{M} / \mathrm{S})}$ WIND

WNW 6.9

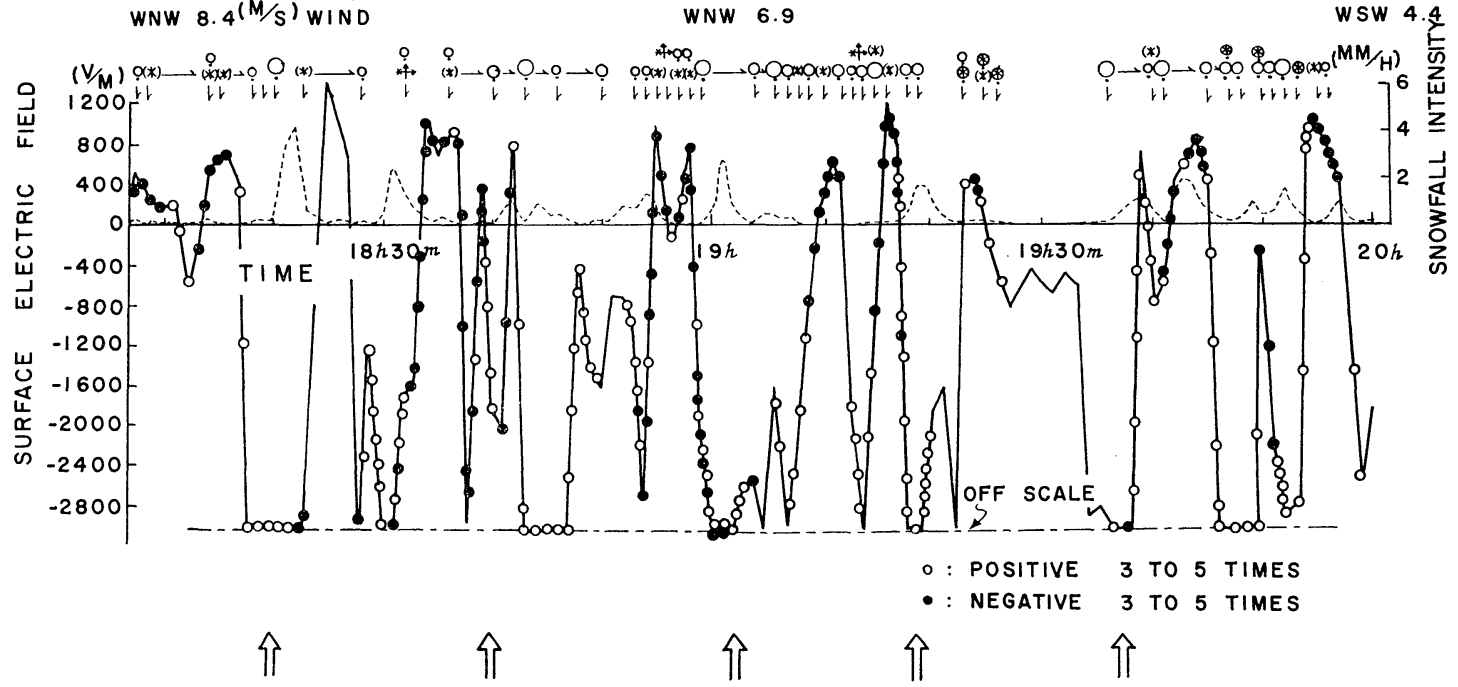

Fig. 5. Charge on snow particle under rapidly changing electric field during successive snow showers, 6 Dec. 1958. 
to be produced under such conditions.

The field pattern in this state seems to be similar to the pattern in the next Fig. $2 \mathrm{c}$, but the following features are quite different, that is to say, the latter pattern has only one maximum of rate of graupel-fall and the charge on snow particles at the positive peak is positive. In other words, the inverse relation does not hold at the positive peak. Therefore the latter pattern is presumed by the "early graupel state" as shown in the upper picture of Fig. $2 \mathrm{c}$. The field patterns observed at $18^{\mathrm{h}} 42^{\mathrm{m}}$ and $19^{\mathrm{h}} 39^{\mathrm{m}}$ 6th Dec. 1958 (Fig. 5) were perhaps produced by such conditions.

It is considered as described hitherto that the gentle change of surface electric field comes from the waved pattern related to the charge distribution in clouds, while the sharp peak is produced by local change of charged snowfall in the immediate vicinity of an observation point. When active cloud cells which generate graupel-fall in a large scale pass over an observation point periodically, the charge distribution as shown in the left hand of Fig. 3 is expected. The authors consider that the typical waved pattern of surface electric field in Fig. 6 corresponds to this type. However such a pattern is frequently disturbed by sudden heavy graupelfall, as seen around $10^{\mathrm{h}} 30^{\mathrm{m}}$, between $11^{\mathrm{h}} 00^{\mathrm{m}}$ and $11^{\mathrm{h}} 25^{\mathrm{m}}$ on 10 th Feb. 1959 (Fig. 4), and around $18^{\mathrm{h}} 20^{\mathrm{m}}, 18^{\mathrm{h}} 30^{\mathrm{m}}, 19^{\mathrm{h}} 05^{\mathrm{m}}, 19^{\mathrm{h}} 20^{\mathrm{m}}$ on 6 th Dec. 1958 (Fig. 5).

According to pictures of radar echoes, active cloud bands have fine structures which perhaps correspond to individual graupel cores with a scale of a few minutes in time. If these graupel cores pass over an observation point, they will give negative or positive sharp peaks to surface electric field such as described in the model of single nimbostratus cumulus (Fig. 2), or give irregular patterns as shown at the center of Fig. 3 .

In the normal induction state, if a small group of graupel-fall occurs, a small depression of electric field as shown in the right end of Fig. 3 will be observed. Such electric patterns were actually observed at $02^{\mathrm{h}} 25^{\mathrm{m}}$ 3rd Feb. 1958 (Fig. 6).

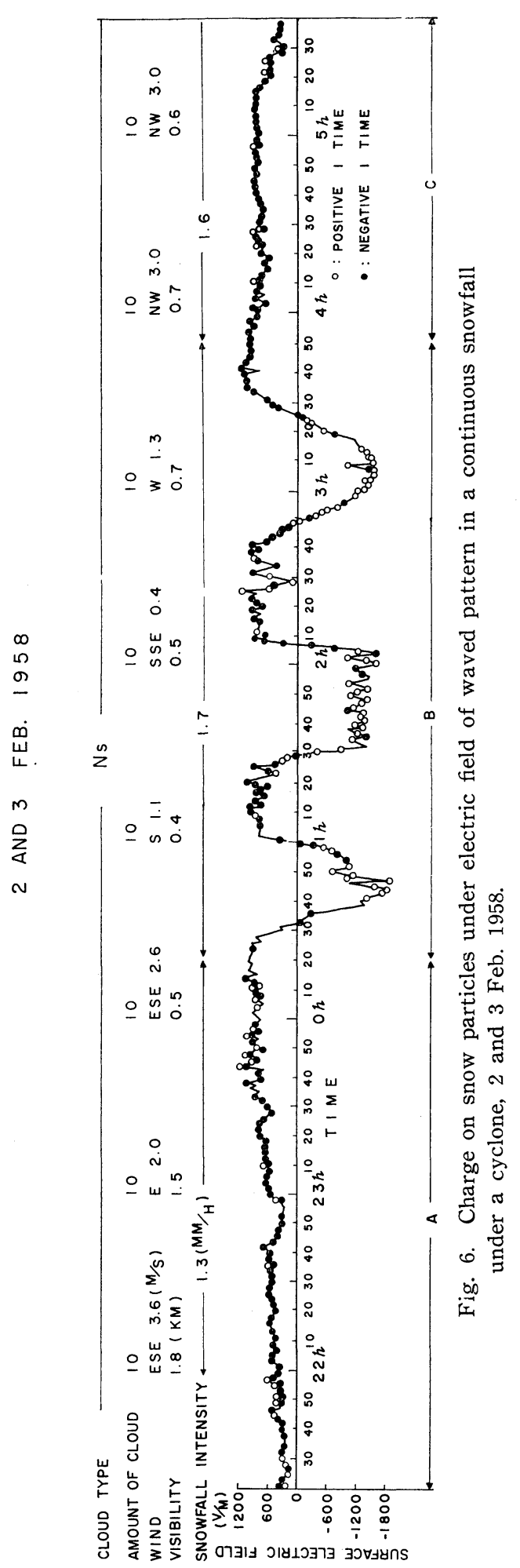




\section{Conclusive remarks}

Several models of charge distribution in and under snowy clouds were proposed, based on the mechanism in which falling rimed snow particles or larger snowflakes are electrified positively by the frictional contact with non-rimed snow crystals or smaller snowflakes in temperatures warmer than $-10^{\circ} \mathrm{C}$. And it seems that the models explain the surface electric field patterns very well, particularly the rapid change in the field.

In the models, it is assumed that the surface electric field is influenced by the space charge only vertically above the observation point. However, lighter snow crystals are usually flown far leeward during fall in the windy weather. It is therefore supposed that the surface electric field would be influenced by the space charge above the area near the observation point. But that is not the case, this means that the rapidly changing surface electric field during snowfall is influenced by the space charge both just above and just near the observation point.

\section{Acknowledgments}

The expense of this work was defrayed by the Special Fund for Sciences of Educational Ministry of Japan.

\section{References}

Magono, C. and K. Orikasa, 1966: On the disturbance of surface electric field caused by snowfall. J. meteor. Soc. Japan, 44, 260-279.

\title{
降雪中の雲の中及び下の電気分布のモデル
}

\author{
孫 野 長 治 \\ 北海道大学理学部地球物理学教室 \\ 織 笠 桂 太 郎 \\ 室蘭工業大学産業機械工学教室
}

前の論文 (On the disturbance of surface electric field caused by snowfall, 本誌 44 巻， 5 号) で降雪中r 生ずる地表電場の種々の型を報告したが, 電場が急激と変動する場合は Wilson の静電誘導説では 説明できない現 象が多かった。そこで $-10^{\circ} \mathrm{C}$ よ温い大氛中では雲粒付の雪が雲粒のつかない雪の結晶と衝突摩擦する際飞正に荷 電する現象と, 地上電場は観測点の直上の空間電荷にだけ左右されるといろ仮定の下で地上電場飞対応する雲中及び 雲下の電荷の分布を想像して説明を試みた。 